\title{
Steppe ecosystems and climate and land-use changes-vulnerability, feedbacks and possibilities for adaptation
}

\author{
Klaus Butterbach-Bahl • Ingrid Kögel-Knabner • \\ Xingguo Han
}

Received: 11 October 2010 /Accepted: 7 November 2010/Published online: 8 February 2011

(C) Springer Science+Business Media B.V. 2011

In temperate zones, grasslands such as steppe cover approximately $20 \%\left(\sim 10^{7} \mathrm{~km}^{2}\right)$ of the land surfaces and are widely used as pasture (Graetz 1994). Grassland soils are one of the most significant stocks for organic carbon. The degradation of grasslands due to changes in management, intensification of rangeland use or climate changes may significantly affect biosphere-atmosphere exchange for carbon and nitrogen due to the volatilization and dislocation by erosion of huge amounts of $\mathrm{C}$ and $\mathrm{N}$ previously stored in the soil (White et al. 2000, Schlesinger et al.

Responsible Editor: Hans Lambers.

\footnotetext{
K. Butterbach-Bahl $(\bowtie)$

Karlsruhe Institute of Technology,

Institute for Meteorology and Climate Research,

Atmospheric Environmental Research (IMK-IFU),

Garmisch-Partenkirchen D-82467, Germany

e-mail: klaus.butterbach-bahl@kit.edu

I. Kögel-Knabner

Lehrstuhl für Bodenkunde, Department für Ökologie und

Ökosystemmanagement, Wissenschaftszentrum

Weihenstephan für Ernährung, Landnutzung und Umwelt, Technische Universität München,

Freising-Weihenstephan D-85350, Germany

X. Han

State Key Laboratory of Vegetation and Environmental Change, Institute of Botany,

Chinese Academy of Sciences,

Beijing 100093, China
}

1990, Ojima et al. 1993). This is in turn associated with soil fertility decline and reduced productivity.

In the recent past temperate grassland research was largely dominated by work carried out in North America (Schlesinger et al. 1990, Goodrich et al. 1994, Hernandez et al. 2000, Frank and Dugas 2001). However, due to the increasing extent of degradation and desertification of grasslands e.g. in China, public awareness on the vulnerability of grassland ecosystems to changes in rangeland management or climate has risen. This was accompanied by an increasing number of research activities on grassland degradation in several regions worldwide with a strong regional focus on grasslands in China and Mongolia.

Most of the contributions summarized in this special issue are reporting on results as obtained from the SinoGerman Research Group MAGIM "Matter Fluxes in Grassland Ecosystems of Inner Mongolia". The MAGIM project, funded by the German Science Foundation (Deutsche Forschungsgemeinschaft, DFG, Research Group 536) with additional support being given by the National Science Foundation of China (NSFC), brought together an interdisciplinary team of scientists from Germany and China with specific expertises in soil science, plant ecology and animal production, micro-meteorology, and biogeochemistry. The regional focus of the project was on steppe systems in the Xilin river catchment of Inner Mongolia (Fig. 1), with Inner Mongolia — besides Tibet—being the most important province in China for grassland based 
Fig. 1 The maps show the location of the Xilin river catchment in Inner Mongolia, China, the location of the Inner Mongolia Grassland Ecosystem Research Station (IMGERS) and the experimental sites where most of the studies of this special issue have been carried out (author: F.K. Barthold)

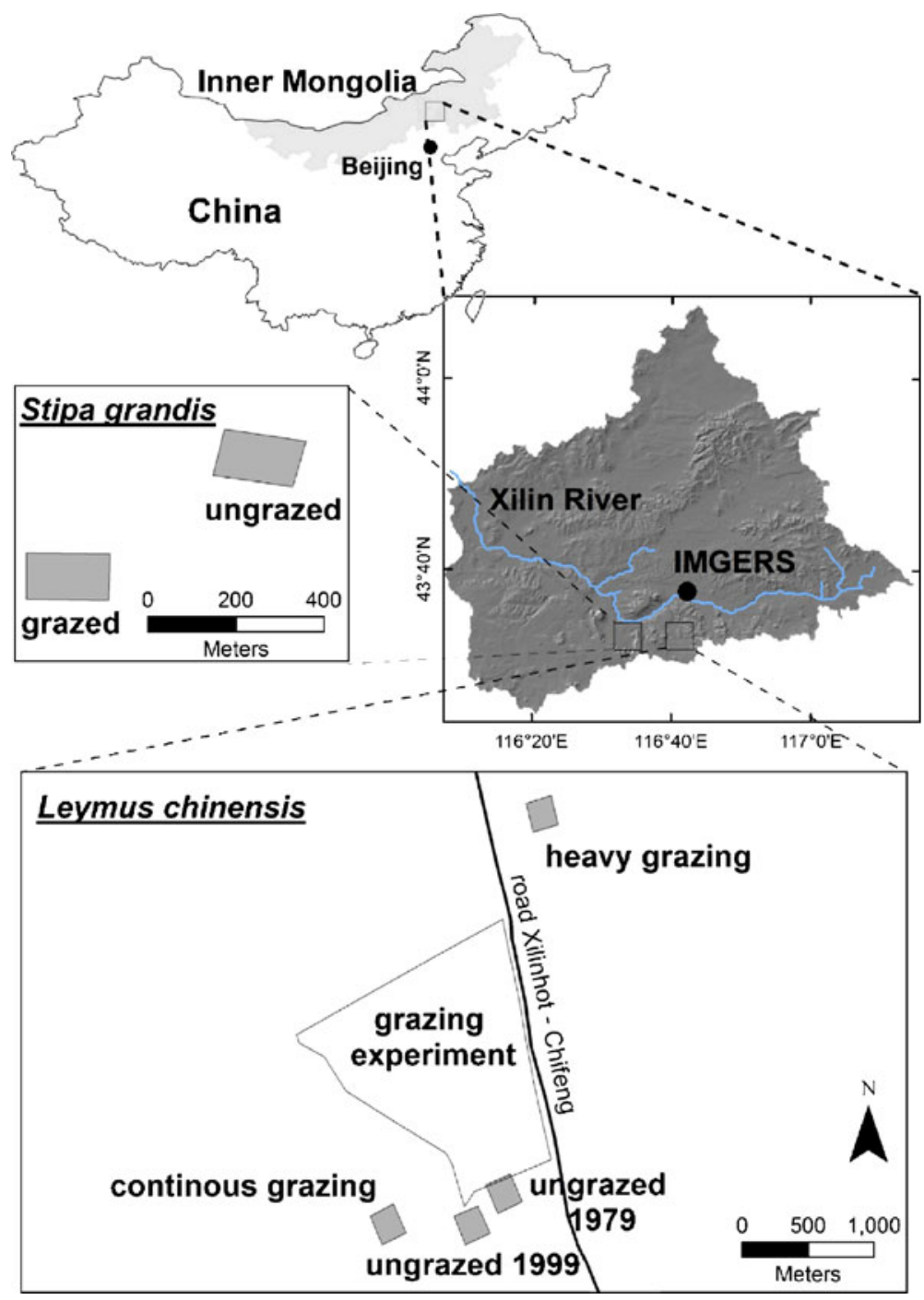

animal husbandry. The Research Group major objectives were to analyzing effects of grazing intensity and an improved grazing system-annual alteration of separated grazing and hay making areas instead of a distinct separation of both areas as traditionally favored by the farmers - on grassland productivity, plant species diversity, soil conditions and nutrient fluxes including biosphere-atmosphere exchange processes. Thus, the research contributes to the development, approval and application of indicator systems for assessing ecological effects of grazing pressure on grasslands in semi-arid climate regions and to the provision of guidelines for a future sustainable use of semi-arid grasslands.
Due to changes in climatic conditions, in particular, declining precipitation, the productivity of grasslands in Inner Mongolia gradually decreases from the E to $\mathrm{W}$ (Yu et al. 2006) and desertification due to overgrazing is a major problem in large areas. The increasing extent of degradation and desertification of grasslands in Inner Mongolia was strongly influenced by political decisions. In the 1950's and 1960's local farmers were forced to give up their nomadic way of life and to settle in small villages, hamlets or individual farms (Sneath 1998). Together with a moderate increase in number of livestock this policy has increased grazing pressure around the newly established settlements and brought the large scale 
pastoral movements between seasonal pastures to an end. The new economic policy established in the 1980's, which allowed individuals to profit directly from increased meat or wool production, sharply fostered the pressure on the land resources and resulted in intensified land-use and large scale overgrazing (Jian and Meurer 2001; Graetz 1994; Fig. 2). E.g. Tong et al. (2004) showed that the total area of degraded steppe in the Xilin river basin, Inner Mongolia, China, increased from approximately $7,200 \mathrm{~km}^{2}$ in 1985 to approximately $7,700 \mathrm{~km}^{2}$ ( $72 \%$ of the total basin) in 1999. In large parts of Inner Mongolia overgrazing has already led to severe losses of soil organic matter, depletion of nutrients (Steffens et al. 2008; Su et al. 2006) and a decrease in steppe primary productivity (White et al. 2000).

Most of the summarized studies in this special issue have been carried out on experimental sites of the Inner Mongolia Grassland Ecosystem Research Station (IMGERS) (Fig. 1), a research platform being part of the Chinese Ecosystem Research Network (CERN) and belonging to the Institute of Botany, Chinese Academy of Sciences, in Beijing. IMGERS is situated in the center of the Xilin river catchment, with Leymus chinensis or Stippa grandis steppe (Bai et al. 2004) being the most common land cover type ( $85 \%$ of the area, Yao et al. 2010). In the Xilin region phaeozems (51\%), chernozems (15\%) and gleysoils

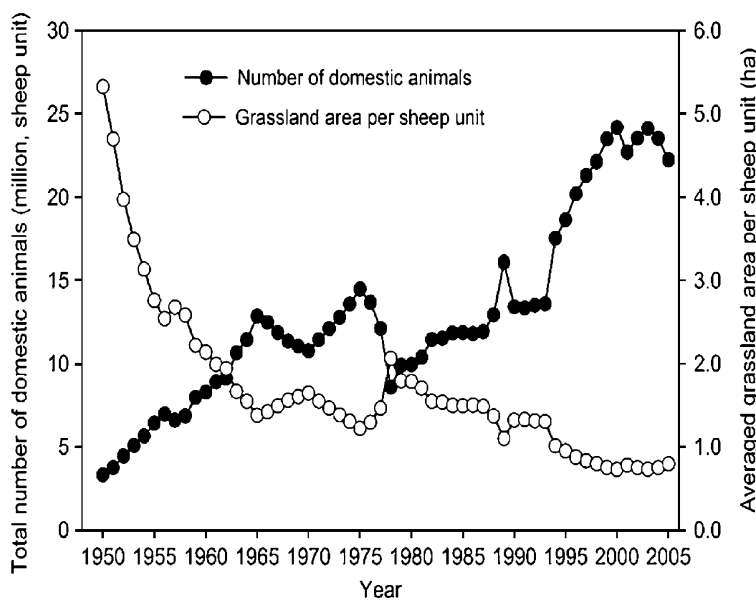

Fig. 2 Changes in livestock numbers in Xilin river catchment region, Inner Mongolia, from 1950-2005. Census data of the Xilinhot county administration, Inner Mongolia, with the Xilinhot county covering most parts of the Xilin river catchment
$(14 \%)$ as well as arenosols $(16 \%)$ in sand dune areas are the dominant soil types (Barthold et al., unpublished). A first detailed study in the region was done by Wiesmeier et al. (2011, this issue) using an innovative digital soil mapping approach to model the spatial distribution of stocks of soil organic carbon, total carbon, total nitrogen and total sulphur for the Xilin river region. The experimental sites encompassed steppe treatment sites where grazing was abandoned since 1979 or later, or where grazing with different intensities were carried out. This experimental approach provided the opportunity to identify grazing effects on a series of ecosystem processes, functions or potential indicators such as stable isotopic composition of ecosystem components (Wittmer et al., 2011, this issue). It is clear from the studies that grazing has a detrimental effect on steppe topsoil properties. Summarizing and integrating current knowledge and recent experimental findings Kölbl et al. (2011, this issue) show that intensive grazing clearly decreased soil aggregation and the amount of fresh, litter-like particulate organic matter. As a consequence of weak aggregation in combination with animal trampling, soil organic matter mineralization is enhanced, whereas topsoil bulk densities were increased and infiltration rates, saturated hydraulic and air conductivities (Reszkowka et al., 2011, this issue) were found to be decreased. The effects of soil structure disruption due to grazing was further amplified by the degradation of vegetation patches and resulted in a texture controlled wettability of the soil surface (Kölbl et al., 2011, this issue). These grazing induced changes within the study area accelerated the influence of soil and vegetation parameters on soil moisture (Schneider et al., 2011, this issue) and lowered soil water storage and plant available water during all seasons (Zhao et al., 2011, this issue).

Degradation in topsoil properties partially explains why aboveground net primary production (ANPP) was negatively affected by grazing intensity (Schönbach et al., 2011, this issue) or why the soil microbial biomass, activity and protozoan abundance was lower at grazed sites as compared to ungrazed sites (Qi et al., 2011, this issue). On the other hand, Wu et al. (2011, this issue) showed that the effect of grazing on gross $\mathrm{N}$ mineralization was non-uniform. At low stocking rates gross $\mathrm{N}$ mineralization tended to decrease but increased with higher grazing pressure. Grazing 
decreased recovery of applied ${ }^{15} \mathrm{~N}$ both in plant and microbial $\mathrm{N}$ pools but strongly promoted $\mathrm{NO}_{3}{ }^{-}$ accumulation in the soil and, thus, negatively affected potential ecosystem $\mathrm{N}$ retention. This appeared to be closely related to the grazing-induced decline in easily degradable soil $\mathrm{C}$ availability at increased stocking rate (Wu et al. 2011, this issue).

Grazing also affected plant functional traits. This was shown in a study dealing with two dominant steppe species, namely Leymus chinensis, a C3 perennial rhizome grass, and Cleistogenes squarrosa, a C4 perennial bunchgrass (Zheng et al. 2011, this issue). The results obtained at sites of the grazing experiment of MAGIM show that $C$. squarrosa is more resistant to grazing, specifically under heavy grazing pressure and in years with below average annual rainfall.

Besides being affected by grazing, ANPP as well as soil ammonium and nitrate availability in the investigated steppe ecosystems (Giese et al. 2011, this issue) was largely dependent on annual rainfall amounts, with the long-term average annual rainfall at the IMGERS station being $330 \mathrm{~mm}$ (Bai et al. 2004). Based on site scale spectral reflectance measurements at differently grazed sites (Fan et al. 2011, this issue; 2008) remote sensing data were used by Schaffrath et al. (2011, this issue) to demonstrate the pronounced effect of interannual rainfall variability on the average leaf area index in the Xilin catchment, with values clearly lower $(\mathrm{LAI}=0.52)$ in dry as compared to wet $(\mathrm{LAI}=0.72)$ years. Furthermore, ANPP may be severely restricted by nutrient availability even under ambient precipitation levels (Ronnenberg and Wesche 2011, this issue), whereas belowground net primary productivity may decline with increased availability of water or nitrogen ( $\mathrm{Li}$ et al. 2011, this issue). The fact that ANPP of the investigated steppe systems is nutrient limited could be further confirmed by the observed plant N:P ratios, which indicate a relative limitation of plant production by $\mathrm{N}$ or $\mathrm{P}$ in the investigated semiarid grasslands under sufficient water supply (Gong et al. 2011a, this issue).

The provided research results show that the investigated steppe ecosystems are extremely sensitive to increases in livestock stocking rates in terms of changes in soil properties and plant production. This should be considered for the development of management strategies to protect these fragile ecosystems from degradation. Liu et al. (2011, this issue) concluded from their observation that plant community ANPP recovered more quickly at sites with low to moderate grazing intensities as compared to heavily grazed sites. They show that periodic grazing cessation may possibly be a management option to sustain long-time productivity. The study of Schönbach et al. (2011, this issue) and Wan et al. (2011, this issue) shows that annual alteration of separated grazing and hay making areas can increase the resilience of the investigated steppe ecosystems with regard to plant biomass production, thereby avoiding sheep-grazing induced plant species shifts. It should also be discussed if low dose fertilization of steppe is a possible means to increase plant production, since e.g. the study of Gong et al. (2011a, b, this issue), Ronnenberg and Wesche (2011, this issue) and Fanselow et al. (2011, this issue) showed that plant nutrient limitation and plant re-growth following grazing can be alleviated by $\mathrm{N}$ fertilization. However, it should also be considered that $\mathrm{N}$ fertilization may lead to a decline in species richness and an increase of ANPP of grasses on costs of forbs (Liu, 2011, this issue).

Besides the need to further explore management options for sustainable livestock management in Inner

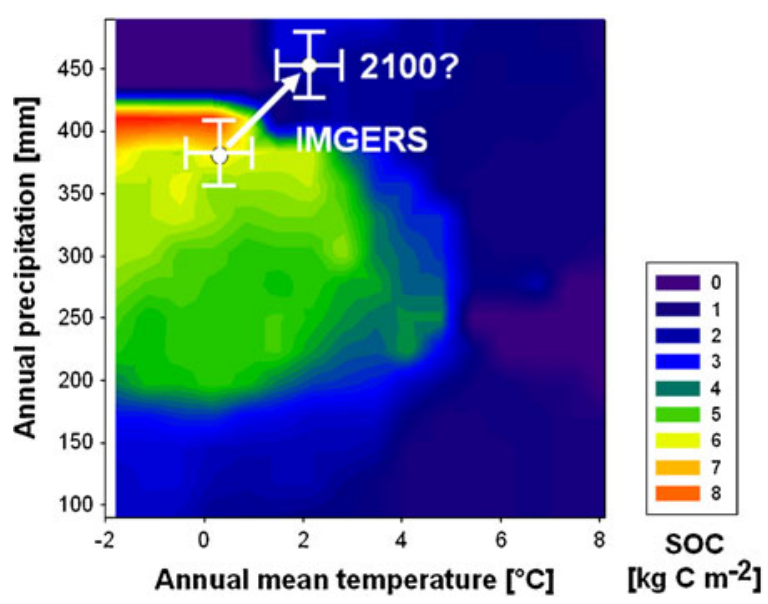

Fig. 3 Soil organic $C$ storage in ungrazed steppe soils (0$0.3 \mathrm{~m}$ ) in dependency of annual mean values of precipitation and temperature. Integration of data was done based on a survey on soil $\mathrm{C}$ storage in ungrazed steppe soils $(N=26)$ by Ojima et al. (1999). The cross shows actual soil organic C storage ( \pm uncertainty) at the ungrazed IMGERS research sites and its possible change under conditions of predicted climate change 
Mongolia one needs to be aware that these fragile ecosystems are further threatened by climate change. The capacity of grassland soils to store huge quantities of $\mathrm{C}$ and $\mathrm{N}$ is a function of climate and land management. Grazing affects the heterogeneity of plant communities (Burke et al. 1998; Evans et al. 2001; Vinton and Burke 1997; Schneider et al. 2011, this issue; Zheng et al. 2011, this issue) and reduces above and belowground productivity. However, the importance of climate for soil $\mathrm{C}$ and $\mathrm{N}$ storage may override management effects in the future. For steppe soils in China and Mongolia there are indications that $\mathrm{C}$ storage is highest when annual rainfall ranges from 350 to $420 \mathrm{~mm}$ and mean annual temperature is $<1^{\circ} \mathrm{C}$ (see Fig. 3) (Parton et al. 1995; Christensen et al. 2004). Prognoses from modelling studies indicate that the change of temperature and precipitation related to climate change will lead to a loss of carbon stock and aboveground net primary productivity in Inner Mongolian steppe ecosystems (Xiao et al. 1995). However, this still remains highly uncertain. Figure 3 indicates that e.g. in the Xilin river catchment soil $\mathrm{C}$ and $\mathrm{N}$ storage might be close to the optimum, i.e. that any change in climate, either increase in temperature or changes in precipitation will lead to a reduction of soil $\mathrm{C}$ and $\mathrm{N}$ storage. However, up to now the temporal timescale of likely changes in soil $\mathrm{C}$ and storage due to changes in climate remains unclear and an interaction with steppe management has so far not been investigated. In view of the importance of steppe ecosystems for regional and global $\mathrm{C}$ balances and as sources and sinks for greenhouse gases (Wolf et al. 2010; Chen et al. 2011 this issue) and in view of the vulnerability of these systems to global changes it is obvious that they deserve further research attention.

Acknowledgements We are grateful to the Sino-German Center for Science Promotion in Beijing for providing funding for a workshop on "Steppe Ecosystems and Climate and LandUse Changes-Vulnerability, Feedbacks and Possibilities for Adaptation" which finally resulted in the compilation of manuscripts provided in this special issue.

\section{References}

Bai Y, Han X, Wu J, Chen Z, Li L (2004) Ecosystem stability and compensatory effects in the Inner Mongolia grassland. Nature 431:181-4

Burke IC, Lauenroth WK, Vinton MA, Hook PB, Kelly RH, Epstein HE, Aguiar MR, Robles MD, Aguilera MO,
Murphy KL, Gill RA (1998) Plant-soil interactions in temperate grasslands. Biogeochem 42:121-143

Chen W, Wolf B, Brüggemann N, Butterbach-Bahl K, Zheng X (2011) Annual emissions of greenhouse gases from sheepfolds in Inner Mongolia. Plant Soil 340: 291-301

Christensen L, Coughenour MB, Ellis JE, Chen ZZ (2004) Vulnerability of the Asian steppe to grazing and climate change. Clim Change 63:351-368

Evans RD, Rimer R, Sperry L, Belnap J (2001) Exotic plant invasion alters nitrogen dynamics in an arid grassland. Ecol Appl 11:1301-1310

Fan L, Gao Y, Brück H, Bernhofer Ch (2008) Investigating the relationship between NDVI and LAI in semiarid grassland in Inner Mongolia using in-situ measurements. Theor. Appl. Climatol. 75: doi: 10.1007/s00704-007-0369-2

Fan L, Ketzer B, Liu H, Bernhofer C (2011) Grazing effects on seasonal dynamics and interannual variabilities of spectral reflectance in semiarid grassland in Inner Mongolia. Plant Soil 340:169-180

Fanselow N, Schönbach P, Gong XY, Lin S, Taube F, Loges R, Pan Q, Dittert K (2011) Short-term regrowth responses of four steppe grassland species to water, nitrogen, and grazing intensity in Inner Mongolia. Plant Soil 340:279-289

Frank AB, Dugas WA (2001) Carbon dioxide fluxes over a northern, semiarid, mixed-grass prairie. Agricul For Meteor 108:317-326

Giese M, Gao Y, Lin S, Brueck H (2011) Nitrogen availability in a grazed semi-arid grassland is dominated by seasonal rainfall. Plant Soil 340:157-167

Gong XY, Chen Q, Dittert K, Taube F, Lin S (2011a) Nitrogen, phosphorus and potassium nutritional status of semiarid steppe grassland in Inner Mongolia. Plant Soil 340:265278

Gong XY, Chen Q, Lin S, Brueck H, Dittert K, Taube F, Schnyder H (2011b) Tradeoffs between nitrogen- and water-use efficiency in dominant species of the semiarid steppe of Inner Mongolia. Plant Soil 340:227-238

Goodrich DC, Schmugge TJ, Jackson TJ, Unkrich CL, Keefer TO, Parry R, Bach LB, Amer SA (1994) Runoff simulation sensitivity to remotely sensed initial soil water content. Water Resourc Res 30:1393-1405

Graetz D (1994) Grasslands. In: Meyer W, Turner B (eds) Change in land use and land cover, a global perspective. Cambridge University Press, Cambridge, pp 287-328

Hernandez M, Miller SN, Goodrich DC, Goff BF, Kepner WG, Edmonds CM, Jones KB (2000) Modeling runoff response to land cover and rainfall spatial variability in semi-arid watersheds. Environ Mon Ass 64:285-298

Jian Y, Meurer M (2001) Die Steppen Nordchinas und ihre Belastung durch weide- und landwirtschaftliche Nutzung. Geogr Rundsch 53:48-52

Kölbl A, Steffens M, Wiesmeier M, Hoffmann C, Funk R, Krümmelbein J, Reszkowska A, Zhao Y, Peth S, Horn R, Giese M, Kögel-Knabner I (2011) Grazing changes topography-controlled topsoil properties and their interaction on different spatial scales in a semi-arid grassland of Inner Mongolia, P.R. China. Plant Soil 340:35-58

Li J, Lin S, Taube F, Pan Q, Dittert K (2011) Above and belowground net primary productivity of grassland influ- 
enced by supplemental water and nitrogen in Inner Mongolia. Plant Soil 340:253-264

Liu X (2011) Impact of nitrogen addition on species richness, plant $\delta^{15} \mathrm{~N}$ and soil mineral nitrogen in a temperate steppe plant community. Plant Soil

Liu Y, Pan Q, Liu H, Bai Y, Simmons M, Dittert K, Han X (2011) Plant responses following grazing removal at different stocking rates in an Inner Mongolia grassland ecosystem. Plant Soil 340:199-213

Ojima DS, Parton WJ, Schimel DS, Scurlock JMO, Kittel TGF (1993) Modelling the effect of climatic and $\mathrm{CO}_{2}$ changes on grassland storage of soil C. Water Air Soil Poll 10:643-657

Ojima DS, Tieszen L, Chuluun T, Belnap J, Dodd J, Chen ZZ (1999) Factors influencing production systems and soil carbon of the Mongolian Steppe. http://www.nrel.colostate. edu/projects/lutea/dennis poster.htm

Parton WJ, Scurlock JMO, Ojima DS, Schimel DS, Hall DO, Scopegram group members (1995) Impact of climate change on grassland production and soil carbon worldwide. Global Change Biol 1:13-22

Qi S, Zheng H, Lin Q, Li G, Xi Z, Zhao X (2011) Effects of livestock grazing intensity on soil biota in a semiarid steppe of Inner Mongolia. Plant Soil 340:117-126

Reszkowka A, Krümmelbein J, Peth S, Horn R, Zhao Y, Gan L (2011) Influence of grazing on hydraulic and mechanical properties of semiarid steppe soils under different vegetation type in Inner Mongolia, China Plant Soil 340:59-72

Ronnenberg K, Wesche K (2011) Effects of fertilization and irrigation on productivity, plant nutrient contents and soil nutrients in southern Mongolia. Plant Soil 340:239-251

Schaffrath D, Barthold FK, Bernhofer C (2011) Spatiotemporal variability of grassland vegetation cover in a catchment in Inner Mongolia, China, derived from MODIS data products. Plant Soil 340:181-198

Schlesinger WH, Reynolds JF, Cunningham GL, Huenneke LF, Jarrell WM, Virginia RA, Whitford WG (1990) Biological feedbacks in global desertification. Science 247:1043-1048

Schneider K, Leopold U, Gerschlauer F, Barthold F, Hoffmann C, Steffens M, Giese M, Frede HG, Breuer L (2011) Spatial and temporal variation of soil moisture in dependence of multiple environmental parameters in semi-arid grasslands. Plant Soil

Schönbach P, Wan H, Gierus M, Bai Y, Müller K, Lin L, Susenbeth A, Taube F (2011) Grassland responses to grazing: effects of grazing intensity and management system in an Inner Mongolian steppe ecosystem. Plant Soil 340:103-115

Sneath D (1998) State policy and pasture degradation in Inner Asia. Science 28:1147-1148

Steffens M, Kölbl A, Totsche KU, Kögel-Knabner I (2008) Grazing effects on soil chemical and physical properties in a semiarid steppe of Inner Mongolia (PR China). Geoderma 143:63-72

Su ZY, Li YL, Zhao HL (2006) Soil properties and their spatial pattern in a degraded sandy grassland under post-grazing restoration, Inner Mongolia, northern China. Biogeochemistry 79:297-314

Tong C, Wu J, Yong S, Yang J, Yong W (2004) A landscape-scale assessment of steppe degradation in the Xilin River Basin, Inner Mongolia, China. J Arid Environ 59:133-149

Vinton MA, Burke IC (1997) Contingent effects of plant species on soils along a regional moisture gradient in the Great Plains. Oecologia 110:393-402

Wan H, Bai Y, Schönbach P, Gierus M, Taube F (2011) Effects of grazing management system on plant community structure and functioning in a semiarid steppe: Scaling from species to community. Plant Soil 340:215226

White R, Murray S, Rohweder M (2000) Pilot analysis of global ecosystems - grassland ecosystems. World Resources Institute, Washington, p 81

Wiesmeier M, Barthold FK, Blank FB, Kögel-Knabner I (2011) Digital mapping of soil organic matter stocks using Random Forest modeling in a semi-arid steppe ecosystem. Plant Soil 340:7-24

Wittmer M, Auerswald K, Schönbach P, Bai Y, Schnyder H (2011) ${ }^{15} \mathrm{~N}$ fractionation between vegetation, soil, faeces and wool is not influenced by stocking rate. Plant Soil 340:25-33

Wolf B, Zheng X, Brüggemann N, Chen W, Dannenmann M, Han X, Sutton MA, Wu H, Yao Z, Butterbach-Bahl K (2010) Grazing-induced reduction of natural nitrous oxide release from continental steppe. Nature 464:881884

Wu H, Dannenmann M, Fanselow N, Wolf B, Yao Z, Wu X, Brüggemann N, Zheng X, Han X, Dittert K, ButterbachBahl K (2011) Feedback of grazing on gross rates of $N$ mineralization and inorganic $\mathrm{N}$ partitioning in steppe soils of Inner Mongolia. Plant Soil 340:127-139

Xiao X, Ojima DS, Parton WJ, Chen Z, Chen D (1995) Sensitivity of Inner Mongolia grasslands to climate change. J Biogeogr 22:643-648

Yao Z, Wolf B, Chen W, Butterbach-Bahl K, Brüggemann N, Wiesmeier M, Dannenmann M, Blank B, Zheng X (2010) Spatial variability of $\mathrm{N}_{2} \mathrm{O}, \mathrm{CH}_{4}$ and $\mathrm{CO}_{2}$ fluxes within the Xilin River catchment of Inner Mongolia-a soil core study. Plant Soil 331:341-359

Yu M, Ellis JE, Epstein HE (2006) Regional analysis of Climate. Primary Production and Livestock Density in Inner Mongolia. J Environm Qual 33:1675-1681

Zhao Y, Peth S, Reszkowska A, Gan L, Krümmelbein J, Peng X, Horn R (2011) Response of soil moisture and temperature to grazing intensity in a Leymus chinensis steppe, Inner Mongolia Plant Soil 340:89-102

Zheng S, Lan Z, Li W, Shan Y, Wan H, Taube F, Bai Y (2011) Differential responses of plant functional trait to grazing between two contrasting dominant $\mathrm{C} 3$ and $\mathrm{C} 4$ species in a typical steppe of Inner Mongolia, China. Plant Soil 340:141-155 